distinguishing one from the other in early stages of the growth of the plant. Until comparatively recent times, traditional methods of weed control in rice fields were hand-weeding and flooding; herbicides were tried, but it was found that many of these, which were effective with barnyard grass, had the unfortunate side-effect of also killing the rice. A few years ago a remarkable, highly selective post-emergence herbicide for use on rice was developed by Rohm and Haas known as 'Stam $F$-34' $\left(3^{\prime}, 4^{\prime}\right.$-dichloropropionanilide); this compound is unique in its selective activity in rice; it kills grasses and broadleaf weeds, but not the rice. An illustrated article in Rohm and Haas Reporter, entitled "How Stam Works", explains the facts (23, No. 3; May-June 1965. Rohm and Haas Company, Philadelphia, Pennsylvania; Lennig Chemicals, Ltd., London, W.C.1). 'Stam' is supplied as an emulsifiable concentrate; after dilution with water, this herbicide is applied as a spray, generally by aerial means. The mechanism by which this product operates is briefly and technically described: simply stated, 'Stam' is deactivated by an amazing enzymatic system in rice; barnyard grass and other weeds infesting rice fields are not able to protect themselves, so they wilt and die, and the rice flourishes. The contrast between a field treated with this product and an untreated plot is strikingly shown in one of the coloured photographs illustrating this article; in sprayed fields, the mature rice crop is seen as a clean stand of golden, rice-laden heads; untreated fields are described as "splotchy with green and brown-with weeds often choking out the rice plants". It is claimed that when 'Stam' is properly applied to a grassy rice field a substantial increase in yield and a finer quality of rice may be expected.

\section{University of Oxford: Vice-Chancellor's Oration}

THE Vice-Chancellor's Oration, which prefaces the annual report for 1964-65 in Supplement No. 3249, of October 1, 1965, to the Oxford University Gazette (University of Oxford. Oration by the Vice-Chancellor and Annual Report, 1964-1965. Pp. 37-56. Supplement to Oxford University Gazette, No. 3249. Oxford: The University, 1965. 2s.) emphasizes the value of the work of the Franks Commission and refers also to the appointment of a Committee on University Libraries under the chairmanship of Mr. R. Shackleton. The annual report, besides noting the appointment of this Committee, refers also to the creation of new graduate societies and to entitlement to fellowships as recommended by the Norrington Committee and to grants from the Common University Fund to the poorer colleges. Matriculated students in residence increased by 487 on the corresponding figures for 1963-64. Candidates entered for the Final Honours School in engineering numbered only 50 compared with 72 in 1963 and 62 in 1964; for physies, the corresponding figures are 140,135 and 159 , respectively; for chemistry, Part I, 180, 141 and 165; for chemistry, Part II, 147, 130 and 115; for biochemistry, 14, 17 and 18; and for mathematics, 130, 91 and 117. An additional $£ 70,000$ was made available to departments for 1964-65 over and above normal growth in expenditure on salaries, including about $£ 28,000$ for new proposals. Most of this went to the creation of 16 new posts of lecturer status, 5 in physical sciences and 2 in biological sciences, and 5 faculty lectureships. A new Diploma in the Science of Materials has also been introduced.

Royal Society of London: Montague Napier Trust Fund

THE Council of the Royal Society has accepted the offer by the Trustees of the late Mr. Montague Napier, one of the pioneers of the motor-car and aeroplane engine industry, of a capital sum of the order of $£ 275,000$. A new trust fund will be formed with this sum, the income from which will be used for research, with the view of ascertaining the cause of cancer, including any corresponding or allied disease and the means of its preven. tion, cure and alleviation. In accordance with the wishes of the Trustees, the income from this Montague Napier Trust Fund for the first five years will be transferred to the Institute of Cancer Research for the purpose of developing the bridge of collaboration, which already exists between the Royal Marsden Hospital and the Institute, for the support and development of those fields of cancer research and cancer treatment generally referred to as 'elinical research'.

\section{Christmas Holiday Films and Talks on Geology}

A sPECral Christmas holiday programme of films and talks will be held at the Geological Survey and Museum, South Kensington. The programme will include: "The Underwater Search" (December 28, film); "North Slope, Alaska", and "Fire Fight at Ahwaz" (December 29, films); "Volcanoes in Britain" (December 29, illustrated lecture); "Landforms from the Air in Canada and Iceland and New Zealand" (December 30, films); "Continents on the Move" (December 30, illustrated lecture); "The Forth Road Bridge" (December 31, film); "Geology with a Camera" (December 31, illustrated lecture); "The Story of Camp Century" and "The Glacier Climbers" (January 1, films); "The Search for Oil in Nigeria" and "Rig Move" (January 3, films); "The Forth Road Bridge" (January 4, film); "Channel Tunnel" (January 4, illustrated talk); "First Catch Your Fossil" (January 5, demonstration). Further information and tickets can be obtained from the Museum Lecturer, Geological Survey and Museum, Exhibition Road, South Kensington, London, S.W.7.

\section{Announcements}

Sir William Hildred, director-general of the International Air Transport Association, has been awarded the Edward Warner Award for 1965 of the Council of the International Civil Aviation Organization, for outstanding contributions to the development of international civil aviation.

ENTRIES are invited for the 1966 "Interaction of Technologies" award, made jointly by the Shell Chemical Company and the British Association for the Advancement of Science. The prize of 250 guineas, and a diseretionary second prize of 100 guineas, will be awarded for the best paper submitted, before February 28, 1966, on the subject "The Problem of Technological Barriers". Further information and forms of application can be obtained from the Secretary, Shell/B.A.A.S. Award, Shell Chemical Co., Ltd., Shell Centre, Downstream Building, London, S.E.1.

A MeEting of the Burton-on-Trent Section of the Institution of the Rubber Industry will be held at Burton-on-Trent on January 31. Further information can be obtained from the Institution of the Rubber Industry, 4 Kensington Palace Gardens, London, W.8.

A course of eight evening lectures on "Modern Physical Aids for the Chemist" will be held at the John Dalton College of Technology, Manchester, commencing on February 8. Further information can be obtained from Mr. P. R. Falkner, John Dalton College of Technology, Chester Street, Manchester 1.

A sEMINAR on "Relations Between the Administration and the Scientific Establishment", arranged by the Science of Science Foundation, will be held at the Ciba Foundation on January 17. Further information can be obtained from the Science of Science Foundation, c/o the Ciba Foundation, 41 Portland Place, London, W.1.

A symposium on "Scientifie Aspects of Pest Control", arranged by the National Academy of Sciences-National Research Council and other United States Federal agencies, will be held in Washington during January 31February 3. Further information can be obtained from the Agricultural Board, National Academy of SciencesNational Research Council, 2101 Constitution Avenue, Washington, D.C. 